\title{
Analysis of Organizational Factors Influencing Staff Performance in Devolved Government in Kenya.
}

\author{
Eric Stanley Muthuri Nthumbi ${ }^{1}$, Dr. Eunice Kirimi ${ }^{2}, \mathrm{Mr}$ Wilson Muema ${ }^{3}$ \\ ${ }^{I}$ A Master Student, Department of Business Administration, Kenya Methodist University \\ ${ }^{2}$ Lecturer and Director, Department of Business Administration, Kenya Methodist University, Meru Town \\ Campus. \\ ${ }^{3}$ Lecturer, Department of Business Administration, Kenya Methodist University, Meru Town Campus.
}

\begin{abstract}
The purpose of this study was to establish the factors affecting staff performance in devolved government. The study was based on the below objective: to find out the effects of politics on performance of staff, at Tharaka Nithi, Embu and Meru County Assemblies. This study was modelled by human capital theory, Adams (1963). This study used a survey study research design. The target population was all the 183 staff members of the Tharaka Nithi, Embu and Meru county assemblies, in the 9 departments. All the workers were purposively sampled for the study. The study utilized a questionnaire for the staff. The content validity of the instruments was ascertained with the help of the research supervisor. Before the actual data collection the researcher piloted the instruments using a test-retest technique and tested the results using Cronbach alpha method. The field data was cleaned by checking for any missing or inaccurate data and correcting it appropriately. After data cleaning, the quantitative data was coded and entered in the computer for analysis using Statistical Package for Social Sciences (SPSS) Version 21 for windows. Multiple regression analysis was used to establish if there was relationship and the nature of the relationship. Qualitative data obtained from the interview was analysed and discussed thematically. This data was used to reinforce the quantitative findings, and to elaborate on the concepts obtained. Quantitative analysis entails analyzing numbers about a situation by choosing specific aspects of that situation. Descriptive statistics was used to analyze the quantitative data obtained. The study established that the level of staff training had an influence on their performance in the county assemblies in the skilled sectors of their jobs. However, the study concludes that the politics had a negative influence on the staff work performance in the County Assemblies, where the politicians tried to dictate their ways and wills to the workers of the county assemblies, through their influence. The Honourable Speakers of the respective county assemblies should ensure that there is minimum political interference. The top management of the county assemblies should be taken for leadership trainings on the emerging issues in the management sectors and the devolved governance.
\end{abstract}

\section{Background to the study}

\section{Introduction}

Employee performance refers to the ability of employees to attain organizational objectives through effective execution of assigned tasks with the aim of achieving organizational goals (Stoner, 2002). The organizational objectives are however achieved through effective execution of assigned tasks by employees under effective supervision. Performance is also a behaviour in which organizations, teams and individuals get work done (Amstrong, 2003). It is the outcome of work as it provides the strongest linkage to the strategic goal of an organization. Employee performance is obtained by measuring individual activities to ensure that organizational goals are consistently being met in an effective and efficient manner (Politt, 2003).

A county is a geographical region a country used for administrative or other purposes. Its etymology derives from the Old French term, conté or cunté and could denote a jurisdiction in mainland Europe, under the sovereignty of a Viscount. Countries that have this form of system worldwide include; Australia, Canada, China, Denmark, France, Germany, Hungary, Iran, Ireland, Italy, Liberia, Nigeria, Uganda, New Zealand, Norway, Poland, Romania, Sweden, Australia, Korea, United Kingdom and United States (ISAC, 2000). Local authorities or county governments are an important element of government in terms of service delivery so as to tackle problems that face local communities; they also create employment in public sector and also account for 15 percent of Kenya's revenue (RoK, 2013).

Countries across the world have reacted differently in managing counties, Beth (2000). Some have been fairly successful while others have failed especially during devolution transition process. In Kenya, for instance, the promulgation of the 2010 new constitution has brought new challenges to the governance of the Municipal Councils. Devolution is generally defined as a process of political, administrative and fiscal management powers between central government and lower levels of government primarily operating at city and region levels, Potter (2001). 
According to Noah (2008), employee involvement in decision making allows the influence of the frontline employees in the planning process. These are the people who are closest to the customer and who can facilitate new product and service recognition, a central element in the entrepreneurial process. This means that employee participation in the planning process surrounding the potential innovations may facilitate opportunity recognition throughout the organization (Zivkovic, 2009).

\section{Statement of the problem}

The government of Kenya is tasked with the responsibility of providing services to its citizens. This is done through the public service. To achieve an effective service delivery, the government has initiated major reforms in the public sector, including county offices. Despite the gains anticipated with the introduction of devolved system of government, concerns have been raised on its impact to staff performance and service delivery in the county government offices. Many at times, the staff in the counties are kept under criticism on issues laxity, and misuse of government funds (Njeri, 2015). Others are linked with a political leader of under qualification with claims being directed to the employees, that they are performing poorly. Generally, the public rating of the devolved government services is generally below the expected. The employee performance concerns are affiliated to political issues, training and leadership styles. However, these are just but speculations, with little or no empirical basis. On the other hand in Tharaka Nithi, Embu and Meru Counties have witnessed numerous strikes by workers, complaining of delayed salaries and poor working terms and conditions. The workers are at times seen complaining about the way their jobs are demanding (Njeri, 2015), others complain of long working hours, while others claim that the Tharaka Nithi and Embu county assemblies do not offer them with supportive services. With numerous studies on job performance, there is paucity of information on Kenyan context of the issue. A study that directly targets the workers in the county Assembly could bring to light to the issues affecting their performance. This study aimed to establish the factors affecting staff performance in devolved governments, in Tharaka Nithi, Embu and Meru County Assemblies, Kenya.

\section{Objectives of the study \\ Main objective}

The purpose of this study was to establish the influence of organizational factors on staff performance in devolved Government in Kenya.

\section{Specific Objective}

i. To investigate the effect of political interference on staff performance in County Assemblies.

\section{Research hypothesis}

The study tested the following hypothesis at significance levels of 0.05

Ho. Political interference does not have a significant effect on performance of staff in County Assemblies

\section{Significance of the study}

The findings of this study will positively contribute to strategic management in general and change management practices in those transiting to a devolved government. This study will inform those charged with staff management during the transition process on the best change management practices and how optimal efficiencies on performance can be maximized.

\section{Limitations of the study}

The following limitations the researcher faced;

Personal characteristics of the respondents may have an effect on data gathering. Some respondents may have failed to exhaustively respond to all items. The researcher attempted to overcome this by building rapport with the respondents and explaining the usefulness of accuracy of information given as education is a crucial service to society.

\section{Assumptions of the Study}

i. The respondents were truthful and gave accurate and honest information free of any bias.

\section{Introduction}

\section{Literature Review}

This chapter presents a review of the related literature, under the following subheadings; review of the theoretical literature, review of the analytical literature, and critical review of literature, summary and gaps to be filled by the study 


\section{Theoretical Literature}

This study was modelled by human capital theory,

\section{Human Capital Theory}

Human Capital theory was proposed by Schultz (1961) and developed extensively by Becker (1976). Schultz (1961) in an article entitled "Investment in Human Capital" introduces his theory of Human Capital. Schultz argues that both knowledge and skill are a form of capital, and that this capital is a product of deliberate organizational growth. The concept of human capital implies an investment in people through education and training. Schultz compares the acquisition of knowledge and skills to acquiring the means of production. The difference in earnings between people relates to the differences in access to education and health. Schultz argues that investment in education and training leads to an increase in human productivity, which in turn leads to a positive rate of return and hence of growth of businesses as well as achievement of organizational objectives. In this theory people are regarded as assets and stresses that investments by organizations in people will generate worthwhile returns.

The theory is associated with the resource based view of strategy developed by Camp (2001), the theory proposes that sustainable competitive advantage is attained when the firm as a human resource pool that cannot be imitated or substituted by its rival. For the employer investments in training and developing people is a means of attracting and retaining people. These returns are expected to be improvements in performance, productivity, flexibility and the capacity to innovate that should results from enlarging the skills base and increasing levels of knowledge and competence.

\section{Theoretical framework}

This study has been guided by 4theories, which include; Human Capital theory, Equity theory, spill over approach and Work-Family Enrichment' (WFE) theory. The human capital theory was proposed by Schultz (1961) and developed extensively by Becker (1964). Schultz (1961) in an article entitled "Investment in Human Capital" introduces his theory of Human Capital. Schultz argues that both knowledge and skill are a form of capital, and that this capital is a product of deliberate organizational growth

\section{Empirical Literature}

\section{Political Factors Affecting Staff Performance}

The politics of management and the management of politics in the workplace have received a great deal of attention due to their image of pervasiveness, mystery, and the potential benefits for those who know how to use them in the struggle over resources. Politics in organizations is thus used to promote interests and gain advantages over competitors in a market-oriented environment but also in non-market areas such as the nonprofit sector and governmental agencies. Even today, after many years of study, organizational politics (OP) enjoys popularity in academic research as well as in the discourse on practical management. Its significance for human resource management (HRM) is one of its least studied aspects, and awaits further theoretical exploration and understanding.

In one of the early writings, Glantz (2002) concluded that "for managers the most appropriate perspective would seem to be to develop a better understanding of politics and how it affects human resources decisions so that its dysfunctional consequences can be prevented". It is our intention to respond to this challenge theoretically, practically, and with the addition of an Israeli culture perspective as noted by Bacharach (2005), politics is an essential skill in managers who wish to get things done. The art of how to get them on your side is crucial at any rank and has human resource implications. However, even today most of the studies that deal with organizational politics suggest that it is a predominantly negative phenomenon (Vigoda, 2003).

Kraines (2001) states that "If I told you, 'you were a very political person,' you would take it either as an insult or at best as a mixed blessing". Ranis and Stewart (2006) argued that the terms "power", "force" and "politics" together create a whole whose general context is far from positive: "Its connotations tend to be more negative than positive, and it has multiple meanings." Similarly, organizational politics is often linked with terms such as cunning, manipulation, subversion, mutual degradation or the achievement of goals in improper ways (Harvey, 2002).

Kamoche (2002), stresses that organizational politics reflect illegitimate force-relations between the organization's members. He contrasts organizational politics with "authority," (Kamoche, 2002) which implies a legitimate force. The negative connotations of force and politics are well noted in the literature. Various studies have examined the harmful effects of political behaviour on employees' performance levels (Vigoda, 2003). This behaviour has negative aspects such as ingratiatory conduct, which lead to a rise in stress and pressure at work, unfairness in evaluating employees' performance, and the formation of negative attitudes towards work among employees with different statuses (Vigoda, 2003). The image arising from these studies corresponds largely to the perceptions of the organizations' members with regard to this phenomenon. 


\section{Critical Review of Literature}

Organizational politics is used in cases of disagreement amongst individuals and frequently, but not always, takes the shape of conflict. Finally, organizational politics is sometimes perceived as a legitimate fight response in times of crisis or when conflicts arise in the organization. Such conditions are usually characterized by the centralization of essential information and by flexibility with regard to methods of action. A balanced, value-free approach towards organizational politics is exemplified by Kumar and Ghadially (1989) who argue that while politics can harm the organization, the organization may also profit from it. Among the negative impacts, they note the risk of losing power and status, hostility from others, an internal feeling of guilt, and reduced performance levels. Among the positive impacts of organizational politics they mention career advancement, recognition and respect from others, enhancement of personal power, realization of personal and organization's goals, a feeling of achievement, nurturing of the ego, self-control and self-realization.

\section{Conceptual framework}

A conceptual framework showing the relationship of the variable of study is shown on below

\begin{tabular}{|l|l|}
\hline Political interference & $\begin{array}{l}\text { Staff performance in } \\
\text { County Assembly }\end{array}$ \\
\cline { 3 - 3 } & Dependent Variable
\end{tabular}

\section{Conceptual framework}

Political interference

Political interference refers to the processes through which these rival interests are played out and eventually reconciled. While in an ideal organisation it may be hoped that decisions are made on a rational basis, politics is inherently non-rational and subject to power interactions between diverse interests. And with the County assemblies managing a wide range of politicians, who include members of the County assembly, political interference is inevitable.

\section{Research Methodology}

\section{Introduction}

This chapter presents the research methodology that includes: design, study population, sampling procedure and sample size, research instruments data collection and analysis and presentation.

\section{Research Design}

Research design refers to the structure of an enquiry. According to Yin (1989), it is a logical matter rather than a logistical one. The central role of research design is to minimize the chance of drawing incorrect causal inferences from data. This study used a descriptive survey research design. The study aimed at collecting information from the selected key informant on factors affecting staff performance in devolved government, in Tharaka Nithi, Embu and Meru County Assemblies. A Case study was ideal for this research since it enabled the researcher to obtain a holistic in-depth investigation on experiences of the subject.

\section{Target population.}

According to Frankel and Wallen (1993) the target population is the larger group to which the researcher hopes to generalize the findings. The target population was all the 183 routine office staff members of the Tharaka Nithi, Embu and Meru county assembly in the 9 departments. sample size

\begin{tabular}{|l|c|l|l|}
\hline \multicolumn{1}{|c|}{ Department } & \multicolumn{2}{c|}{ Number of Staff } & Embu \\
\cline { 2 - 4 } & Tharaka Nithi & Meru & 12 \\
\hline Speakers Office & 6 & 9 & 14 \\
\hline Clerks/Administration & 8 & 11 & 9 \\
\hline Finance & 7 & 9 & 15 \\
\hline Hansard & 5 & 12 & 7 \\
\hline Sergeant at Arms & 5 & 2 & 3 \\
\hline Audit & 1 & 2 & 3 \\
\hline Information Communication Technology & 2 & 2 & 2 \\
\hline Legal & 1 & 2 & 11 \\
\hline Human Resource & 7 & 10 & $\mathbf{6 3}$ \\
\hline Total & $\mathbf{4 3}$ & $\mathbf{6 3}$ \\
\hline
\end{tabular}

(Source: Tharaka Nithi, Embu and Meru county assemblies’ human Resource offices) 


\section{Sampling Design}

Orodho (2008) defines a sample as part of large population, which is a representative of the larger population. Sampling is a process of selecting a number of individuals or objects from a population such that the selected group contains elements representatives of characteristics found in the entire group. For this study, a census sampling was used owing to the small number of targeted population. All the workers who run the day to day activities of the assemblies were considered for this study. This brought the sample to 183 respondents.

\section{Research instruments}

The study utilized a questionnaire for the staff. The questionnaire were used for data collection because as Kiess and Bloomquist (1985) observe and that questionnaires offer considerable advantage in administration, presents an even stimulus potentiality to large numbers of people simultaneously and provides the investigation with an easy accumulation of data. Gay (1992) maintains that questionnaires give respondents freedom to express their views or opinion and also to make suggestions. It's on the basis of these strengths that the instruments were chosen.

\section{Piloting of Instruments}

According to Gay (1992), it is recommended that researchers pilot $10 \%$ of the preset sample of the target population. The researcher collected data from 3 departments in the neighbouring Isiolo County. A pilot study is important as it enabled the researcher to gather information that aids in improving reliability and validity of a research instrument. Piloting the research instrument enabled the researcher to familiarize with data collection procedures. Piloting also enabled the researcher to test the reliability of the instrument and to identify any items in the instrument that are ambiguous or unclear to the respondents and change them effectively.

\section{Validity of the Instruments}

According to Borg and Gall (1989), validity of an instrument is improved through expert judgment. As such, the content validity of the instruments was ascertained with the help of the research supervisor. When an agreement was obtained, then the instruments were deemed to have content and face validity.

\section{Reliability of the Research Instrument}

Reliability is a measure of the degree to which a research instrument yields consistent results after repeated trials (Mugenda \& Mugenda, 1999). Before the actual data collection the researcher piloted the instruments using a test-retest technique and tested the results using Cronbach alpha method (Orodho 2008). The method was used to estimate the degree to which the same results can be obtained within a repeated measure of the same concept. A correlation coefficient of at least 0.89 for the two halves was obtained and hence considered high enough to judge the reliability of the instrument.

\section{Procedure for Data Collection}

After approval of research proposal, the researcher obtained an introductory letter from School of Postgraduate of Kenya Methodist University and research permit from National Commission for Science, Technology and Innovations. The researcher visited the Tharaka Nithi, Embu and Meru county assemblies where research was conducted and introduced himself to people who he interacted with and created rapport. The administration of data collection instruments was done by the researcher both at pilot and main study. The researcher took a period of 4 weeks.

\section{Data Analysis Procedures}

The field data was cleaned by checking for any missing or inaccurate data and corrected it appropriately. After data cleaning, the quantitative data was coded and entered in the computer for analysis using Statistical Package for Social Sciences (SPSS) Version 21 for windows. Martin and Acuna (2002) posit that SPSS is able to handle large amount of data, and given its wide spectrum of statistical procedures purposefully designed for social sciences, it is quite efficient. Quantitative analysis entails analyzing numbers about a situation by choosing specific aspects of that situation. Descriptive statistics was used to analyze the quantitative data obtained. This specifically included percentages frequency counts, and inferences to test the relationship between the dependent and the independent variables. Regressions analysis was carried out to establish relationship between independent and dependent variable and to test the hypothesis of the study at $95 \%$ significance level.

$$
\begin{gathered}
\mathrm{Y}=\beta_{\mathrm{O}}+\beta_{1} \mathrm{X}_{1}+\beta_{2} \mathrm{X}_{2}+\ldots \ldots \ldots \beta_{\mathrm{n}} \mathrm{X}_{\mathrm{n}}+\varepsilon \\
\text { Where: } \mathrm{Y}-\text { is the dependent variable } \\
\mathrm{X}_{1-\mathrm{n}}-\text { are the independent variables } \\
\beta_{\mathrm{O}} \quad \text { - is the constant }
\end{gathered}
$$


$\beta_{1-n^{-}}$are the regression coefficients or change induced in $\mathrm{Y}$ by each $\mathrm{X}$

$\varepsilon \quad$ - is the error

Qualitative data obtained from the interview were analysed and discussed thematically. This data was used to reinforce the quantitative findings, and to elaborate on the concepts obtained.

\section{Introduction}

\section{Findings And Discussion}

This chapter covers the analysis of data and presentation of results for the study. The data presented covers respondents' demographic data that includes gender, age and academic qualifications. The chapter presents the results and discussion of the study objectives.

\section{Data Analysis, Presentation and Interpretation}

The study was guided by the following objectives:

i. To investigate the effect of political interference on staff performance in County Assemblies.

\section{Response Rate}

The research instruments were administered to the subjects and the response rate

\section{Response Rate}

\begin{tabular}{|l|l|l|l|l|}
\hline \multirow{2}{*}{ County } & Response & \multicolumn{2}{|c|}{ Non Response } \\
\cline { 2 - 5 } & Frequency & Percent & Frequency & Percent \\
\hline Tharaka Nithi & 40 & 93.3 & 3 & 6.7 \\
\hline Embu & 71 & 93.4 & 5 & 6.6 \\
\hline Meru & 60 & 95.2 & 3 & 4.8 \\
\hline Total & $\mathbf{1 7 1}$ & & $\mathbf{1 1}$ & \\
\hline
\end{tabular}

The study involved 171 subjects that comprised the county assembly staff from the three county assemblies in eastern region. . Data on Table 4.1 indicates that $(93.3 \%)$ of the county assembly staff from Tharaka Nithi county participated in this study. The study further established that $93.4 \%$ of Embu county assembly staff and $95.2 \%$ of Meru county assembly staff participated in this study. Finchman (2008) stated that response rates approximating above $60 \%$ for most research should be the goal of researchers.

\section{Demographic Data of Respondents}

The demographic profile provides information about the population structure, and helps create a mental picture of the subgroups that exist in the overall population. Researchers obtain demographic information from the study subjects to understand sample characteristics and to determine if samples are representative of the populations of interest. In this study, the researcher investigated the respondents' characteristics by establishing their gender, age and academic qualifications.

\section{Gender of the respondents}

The study sought to establish how the sample population was distributed by gender, and enable cross tabulation of response in this light. Table 4.2 data reveals how the study subjects were distributed by gender.

\section{Gender Distribution of Respondents}

\begin{tabular}{|l|l|l|l|l|}
\hline \multirow{2}{*}{ Category } & Male & Female \\
\cline { 2 - 5 } & Frequency & Percentage & Frequency & Percentage \\
\hline Workers & 90 & 58.3 & 78 & 41.7 \\
\hline Human resource Managers & 2 & 66.7 & 1 & 33.3 \\
\hline Total & $\mathbf{9 2}$ & & $\mathbf{7 9}$ & \\
\hline
\end{tabular}

The data shows that $58.3 \%$ workers were male as compared to $41.7 \%$ females. The data also indicates that majority (66.7\%) human resource managers were male as compared to $(33.3 \%)$ female. The overall gender of the population indicates that $51.9 \%$ of the respondents were male while $48.1 \%$ were female. It can be concluded from the findings that gender was fairly distributed in the sample population.

\section{Academic Qualification}

The study sought to establish the academic qualifications of the employees and the results are elicited in figure 4.1 


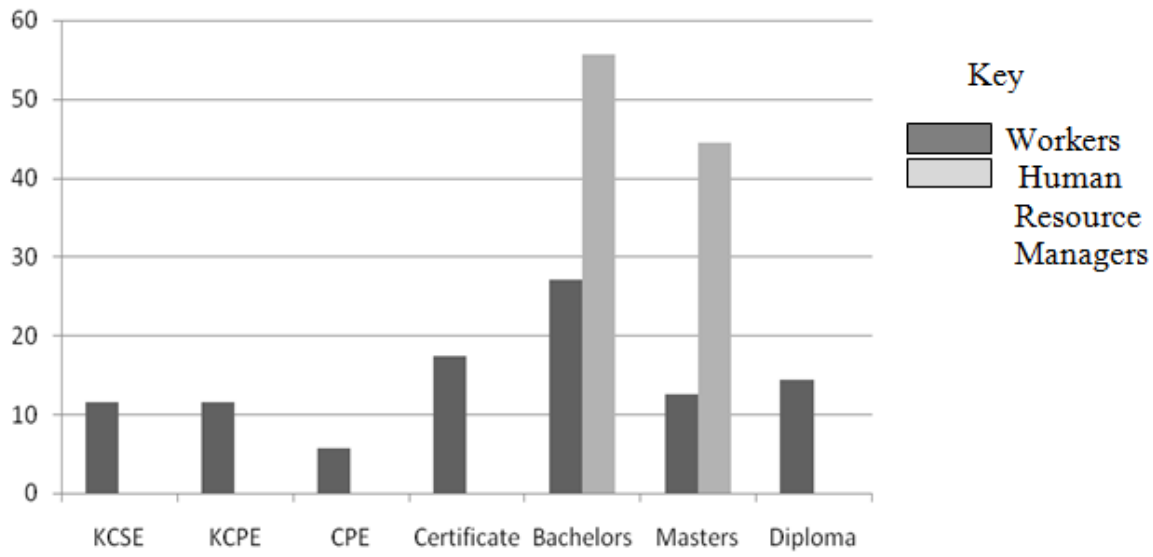

\section{Academic Qualification of the workers}

The data in the figure 4.1 above shows that the majority (28\%) of the workers had a bachelors degree, (17\%) had a masters degree while only $14.3 \%$ of the workers had diploma. The study further established that the majority $(55.6 \%)$ of human resource managers had a bachelor's degree, while (44.4\%) had a master's degree. These findings indicate that the workers and management met the qualifications and training.

\section{Position held in the Organizations}

The study further sought to establish the position the respondents held in the County assemblies. The findings obtained are presented on the figure below.

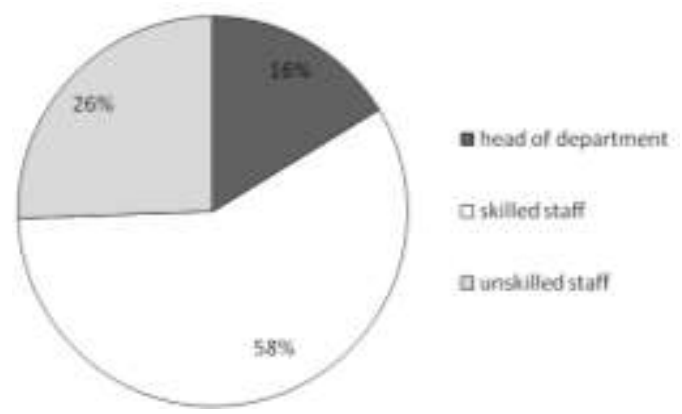

\section{Position held in the Organization}

The study established that the majority (58\%) of the respondents were the skilled staff, $26 \%$ were unskilled while $16 \%$ were the heads of departments.

\section{Organization Performance in the County Assemblies}

The dependent variable for this study was the organizational performance. The study sought to explore the variables of organizational performance in the County assemblies. Employee performance is obtained by measuring individual activities to ensure that organizational goals are consistently being met in an effective and efficient manner (Politt, 2003). The study sought to establish if the organizational performance has improved in the last 2 years and the results obtained are presented on the figure 4.3.

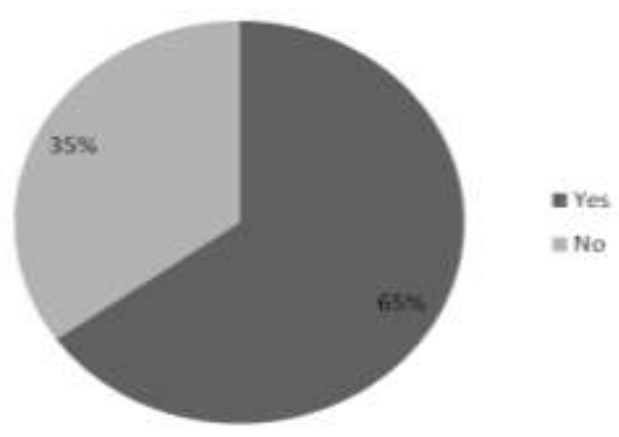




\section{Improvement of performance of Organization}

The study established that the majority (65\%) of the respondents agreed that indeed the organizations' performance had improved. The study further sought to establish what the workers thought to have contributed to the growth. The findings are then presented on the figure 4.4.

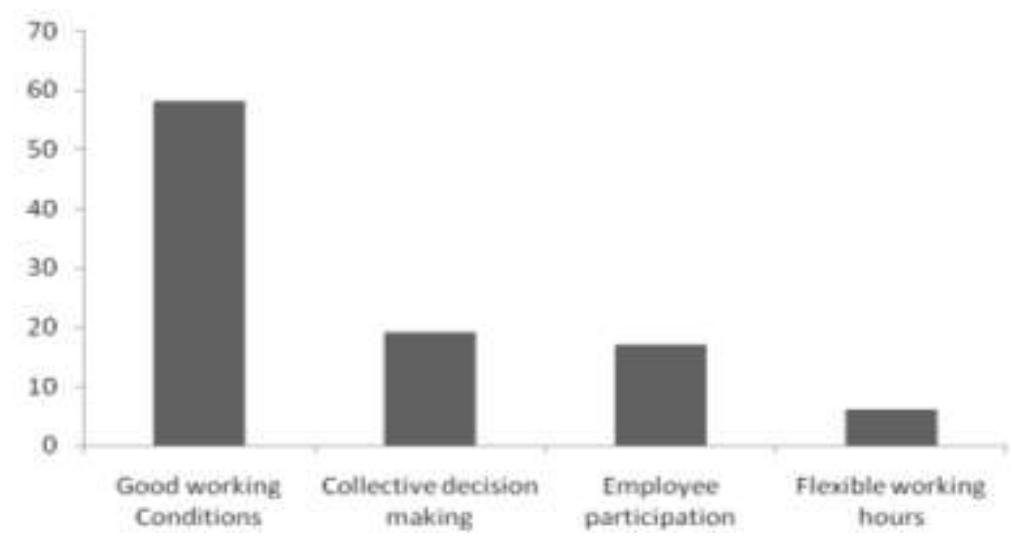

\section{Contributors to the Growth}

The study established that the majority (58\%) of the respondents agreed that good working conditions at the county assembly offices led to the growth of the organizations. The study further established that (19\%) of the workers were of the opinion that employee participation contributed to growth of the organizations. The study further sought to establish from the workers what would be the main source of poor performance and the results are presented on the table 4.3.

\section{Main sources of Poor Performance}

\begin{tabular}{|l|l|l|}
\hline Category & Frequency & Percentage \\
\hline Lack of motivation & 20 & 11.6 \\
\hline Long working hours & 75 & 44.2 \\
\hline Lack of effective communication & 48 & 27.9 \\
\hline Poor working conditions & 12 & 7.0 \\
\hline Lack of promotion & 16 & 9.3 \\
\hline Total & 171 & 100 \\
\hline
\end{tabular}

The study established that the majority $(44.2 \%)$ of the respondents agreed that long working hours was one of the causes of poor performance, while $27.9 \%$ agreed that lack of effective communication was a huge cause of poor performance. Nevertheless, even if, or when, there is no effect on employees' work/life conflict, work/life balance practices such as flexitime are often associated with improved organizational performance

\section{Effects of Political Interference on Performance of Staff in County Assemblies}

The study sought to find out how political interference affect performance of staff in county assemblies. The findings obtained are presented on a 5-point likert scale, and presented on the table below, where; $\mathrm{S} . \mathrm{A}=($ Strongly Agree) $\mathrm{A}=($ Agree $), \mathrm{U}=($ Undecided $), \mathrm{D}=($ Disagree $)$ and $\mathrm{S} . \mathrm{D}=$ (Strongly Disagree $)$.

\section{Effects of Political Interference on Performance of Staff in County Assemblies}

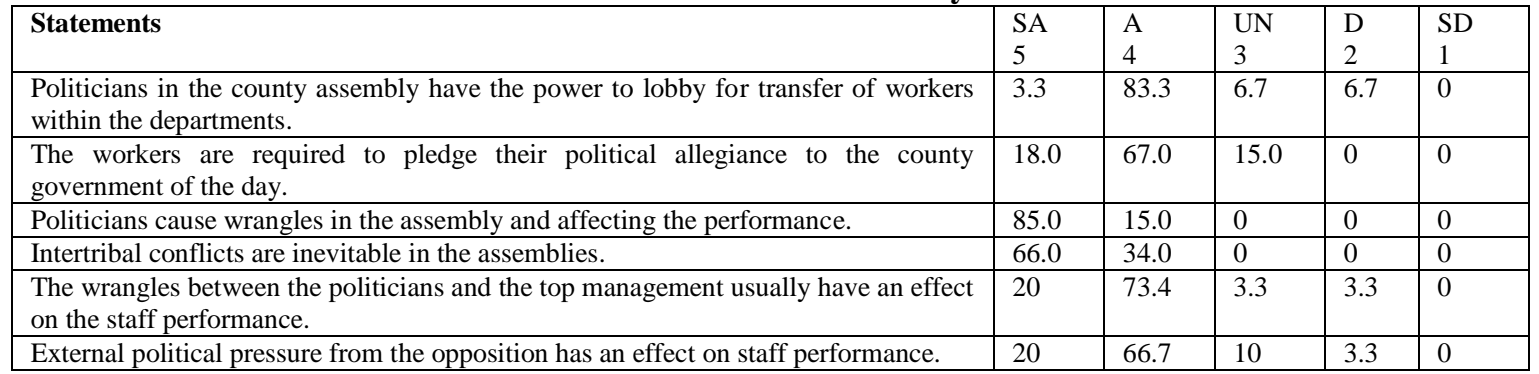

The study established that the majority $(83.3 \%)$ of the respondents indicated that the politicians in the county assembly had the power to lobby for transfer of workers within the departments. Similarly, organizational politics is often linked with terms such as cunning, manipulation, subversion, mutual degradation or the achievement of goals in improper ways (Harvey, 2002). 
The study further established that the workers are required to pledge their political allegiance to the county government of the day, as was revealed by $67.0 \%$ of the respondents. In one of the early writings, Glantz (2002) concluded that "for managers the most appropriate perspective would seem to be to develop a better understanding of politics and how it affects human resources decisions so that its dysfunctional consequences can be prevented".

The study further established that $85.0 \%$ of the respondents indicated that politicians cause wrangles in the assembly hence affecting the performance. Ranis and Stewart (2006) argued that the terms "power", "force" and "politics" together create a whole whose general context is far from positive: "Its connotations tend to be more negative than positive, and it has multiple meanings." The study further established that $66.0 \%$ of the respondents indicated that intertribal conflicts are inevitable in the assemblies

The study further established that the wrangles between the politicians and the top management usually have an effect on the staff performance, as was revealed by $73.3 \%$ of the respondents. A study conducted by Devins and Johnson, (2002) found that employees usually consider organizational politics to be an unfair, evil, irrational and unhealthy behaviour but at the same time as a necessary skill for those who want to get ahead and be promoted in the workplace.

The study further established that $66.7 \%$ of the respondents indicated that external political pressure from the opposition had an effect on staff performance. Kamoche (2002), stresses that organizational politics reflect illegitimate force. He contrasts organizational politics with "authority," (Kamoche, 2002) which implies a legitimate force. The negative connotations of force and politics are well noted in the literature.

The second hypothesis of the study was; Politics do not have a significant effect on performance of staff in county assemblies. The researcher used Multiple Regression to calculate the independent contributions of each of the variables of political interference to performance in county assemblies and the results are shown in Table 4.7

Multiple Regression Coefficients ( $\beta$-coefficients) by Political Interference Variables on Staff Performance

\begin{tabular}{|l|l|l|l|}
\hline Political Influence Variables & $\boldsymbol{\beta}$-Coefficient & $\mathbf{t}$ & $\mathbf{S i g}$ \\
\hline $\begin{array}{l}\text { Politicians in the county assembly have the power to lobby for transfer } \\
\text { of workers within the departments. }\end{array}$ & 0.186 & 3.151 & 0.002 \\
\hline $\begin{array}{l}\text { The workers are required to pledge their political allegiance to the } \\
\text { county government of the day. }\end{array}$ & 0.170 & 1.028 & 0.006 \\
\hline $\begin{array}{l}\text { Politicians cause wrangles in the assembly and affecting the } \\
\text { performance. }\end{array}$ & -0.039 & -0.419 & 0.650 \\
\hline Intertribal conflicts are inevitable in the assemblies. & 0.362 & 0.999 & 0.002 \\
\hline $\begin{array}{l}\text { The wrangles between the politicians and the top management usually } \\
\text { have an effect on the staff performance. }\end{array}$ & 0.771 & 3.500 & 0.000 \\
\hline $\begin{array}{l}\text { External political pressure from the opposition has an effect on staff } \\
\text { performance. }\end{array}$ & 0.674 & 0.000 \\
\hline
\end{tabular}

The statistics attempted to determine whether the political interference variables predict workers performance. A $\beta$-coefficient value near zero indicates no relationship between the independent and dependent variables. The significant independent variables were: Politicians in the county assemblies have the power to lobby for a transfer of workers within the departments $(\beta=0.186)$, intertribal conflicts are inevitable in the assemblies $(\beta=0.362)$, the wrangles between the politicians and the top management usually have an effect on the staff performance $(\beta=0.771)$ and that external political pressure from the opposition has an effect on staff performance $(\beta=0.674)$. Bacharach (2005) noted that, politics is an essential skill in managers who wish to get things done. The art of how to get them on your side is crucial at any rank and has human resource implications. However, even today most of the studies that deal with organizational politics suggest that it is a predominantly negative phenomenon (Vigoda, 2003).

\section{Introduction}

\section{Summary, Conclusions And Recommendations}

In this chapter, a summary of the main study findings is presented, together with a conclusion of the study. The chapter further covers recommendations of the study, as well as suggestions for further research.

\section{Summaries of the Main Findings}

The study established that the majority (69.0\%) of the respondents revealed that the employees with academic qualification interact with their clients respectfully. The study further established that staff with professional qualification use problem-solving methods effectively, as was revealed by $53.0 \%$ of the respondents who agreed. The study further established that the majority $(54.0 \%)$ of the workers with academic qualification demonstrate familiarity with co-workers effectively. The study further established that the majority (92.0\%) of the workers with professional qualification encourage co-workers to work effectively. The study 
established that $59.4 \%$ of the respondents indicated that employees with academic qualification select appropriate responses to situations arising at the workplace. The study further established that the employees with academic qualification construct various evaluation instruments effectively, as was revealed by the majority (71.0\%) of the respondents. The study further established that the workers with academic qualification ensure effective time management, as was indicated by $97.0 \%$ of the respondents. The study established that the majority (62.9\%) of respondents indicated that the workers with academic qualification show sufficient mastery of content matters.

The study established that the majority $(83.3 \%)$ of the respondents indicated that the politicians in the county assembly have the power to lobby for a transfer of staff within the departments. The study further established that the employees are required to pledge their political allegiance to the county government of the day, as was revealed by $67.0 \%$ of the respondents. The study further established that $85.0 \%$ of the respondents indicated that politicians cause wrangles in the assembly hence affecting the staff performance. The study further established that $66.0 \%$ of the respondents indicated that intertribal conflicts are inevitable in the assemblies. The study further established that the wrangles between the politicians and the top management usually have an effect on the staff performance, as was revealed by $73.4 \%$ of the respondents. The study further established that $66.7 \%$ of the respondents indicated that external political pressure from the opposition has an effect on staff performance.

\section{Conclusions}

Based on the findings of this study, the researcher makes the following conclusions;

i. The study further concludes that political interference had a negative influence on the staff performance in the County Assemblies, where the politicians tried to dictate their ways and wills to the workers of the county assemblies, through their influence.

\section{Recommendation}

Based on the findings of the study, the researcher recommends that

i. The human resource managers should allocate budgetary funds to facilitate training for the workers to enhance skills development in work performance, feedback services and service delivery. This should often be done through needs assessments.

ii. The Honourable Speakers of the respective county assemblies should ensure that there is minimum political interference. This should be done through regular informal meetings (kamukunji), benchmarking, seminars on leadership and professionalism for all the MCAs.

\section{References}

[1] Adams, J. (1963). Toward an understanding of inequity. Journal of Abnormal Psychology, 67, 422-436.

[2] Armstrong, M. (2003). A Handbook of Human Resource Management Practice (9th ed). London: Kogan Page Ltd

[3] Becker, G. (1976). Human Capital. New York: National Bureau of Economic Research.

[4] Borjas, G. (2012). Labour economics. Irwin: McGrawHill.

[5] Brown, M. , Trevino, L., \& Harrison, D. (2005). Ethical leadership: A social learning perspective for construct development and testing. Organizational Behaviour and Human Decision Processes, 97, 117-134.

[6] Brum, S. (2007). What impact does training have on employee commitment and employee turnover? Schmidt Labour Research Centre Seminar Research Series. 1-13

[7] Bulut, C. \& Culha, O. (2010). The effects of organisational training on organisational commitment. International Journal of Training and Development, 14(4):309-322.

[8] Camp, W. (2001). Formulating and evaluating theoretical frameworks for the career and technical education research. Journal of Vocational Educational Research, 26-30

[9] Chang, G., \& Lorenzi, P. (1983) The Effects of Participative versus Assigned Goal Setting on Intrinsic Motivation. Journal of Management, 9: 55-64.

[10] Collins, D. (1995). Rooting for Empowerment? Empowerment in Organizations Journal, Vol. 3, No. 2, pp. 25-33. http://dx.doi.org/10.1108/09684899510089301

[11] Croft, S. and Dalton, J. (2003) Managing corporate reputation, the new currency, Publisher Thorogood

[12] Devins, D. \& Johnson, S. (2002). Engaging SME managers and employees in training: Lessons from an evaluation of ESF objective 4 programme in Great Britain. Journal of Education and Training, 8(9): 370-377.

[13] Duckett .H. \& Macfarlane, E (2003). Emotional Intelligence and Transformational Leadership in Retailing Leadership \& Organization Development Journal, Vol. 24, pp.309-317

[14] Edwards, J, \& Rothbard, N. (2000). Mechanisms linking work and family: Clarifying the relationship between work and family constructsll. Academy of Management Review, 25, 178-199.

[15] Emiliani, M. (2006). Executive decision-making traps and B2B online reverse auctions. Supply chain management, 6-9.

[16] Galloway, J. (1997). Implementing scientific practices through case studies: Examples using home-school interventions and consultation. Journal of School Psychology, 32(4) 385-413.

[17] Gay, L. (1981). Educational Research Competencies for Analysis and Application: New Yolk: Ohio Macmillan Publisher.

[18] Gay, L. (1992). Educational Research Competences for Analysis and Application. Ohio: Charles E. Merrill Publishing Co.

[19] Glantz, J. (2002) Finding Your Leadership Style: A Guide for Educators, Association for supervision and curriculum development .

[20] GOK, (2010). Sector Performance Standards (SPS) 2009-2030: Final Report. Nairobi, Kenya: Government Press. 
[21] Greenhuas, J, \& Powell, G. (2006). When work and family are allies: A theory of work-family enrichmentll. Academy of Management Review, 31, 72-92.

[22] Hall, C. (2003). Profile of small-medium enterprises in the Asia-pacific economic cooperation economies. Journal of Enterprising Culture, 11(3):173-337, September.

[23] Harvey, M. (2002). Human Resource Management in Africa: Alice's Adventures in Wonderland. International Journal of Human Resource Management. 13,7, 1119-1145.

[24] Kamoche, K. (2002). Introduction: Human Resource Management in Africa. International Journal of Human Resource Management. 13,7, 993-997.

[25] Kanyinga, K. (2000) Redistribution from Above: The politics of land rights and squatting in coastal Kenya, Nordiska Afrikainstitutet, Research Report No. 115, The Nordic Africa Institute, Uppsala, Sweden.

[26] Kathuri, J. \& Pals, D. (1993). Introduction to Educational Research. Educational Media Centre, Egerton University. Njoro: Kenya.

[27] Kemelgor, B. (2002) A Comparative Analysis of Corporate Entrepreneurial Orientation between Selected Firms in the Netherlands and the U.S.A. Entrepreneurship and Regional Development, 14: 67-87.

[28] Kerlinger, F. (1973). Foundation of Behavioural Research. New York: Holt Rinehart.

[29] Khatri, G. (2000). Managing human resources for competitive advantage. International journal of human resource management Vol11(2), 336-365.

[30] Kombo, D. \& Tromp, D. (2006). Proposal and Thesis Writing: An Introduction. Nairobi: Pangoline Publications Africa.

[31] Lindner, L. (1998). Understanding Employee Motivation, Journal of Extension, Vol. 36 No. 3.

[32] Lyson, K., \& Brewer, R. (2003). Managing human resources in purchasing and supply. Stamford: CIPS.

[33] Marangu, K. (2004). A Thesis on Performance Improvement in Kenya Civil Service. Nairobi, KEN: ESAMI.

[34] Morris, M., \& Madsen, S. (2007). Advancing work-life integration in individuals, organizations and communities (Special Edition). Advances in Developing Human Resources, 9, 439-454.

[35] Mugenda, A. \& Mugenda, O. (1999) Research Methods, Quantitative and Qualitative Approach. Nairobi: Act Press.

[36] Muia J. (2008) Decentralization in Africa: Trends and Prospects for the Twenty First Century. in W. B. Stohr, J. S. Edralin \& D. Mani (eds.), Decentralization, Governance and the New Planning for the Local-Level Development. London: Greenwood Press.

[37] Munene, T. (2010). Performance management: the new realities. Mumbai: Jaico publishing house.

[38] Noah, Y. (2008) A Study of Worker 14 Kuye/ SJM 6 (1) (2011) 1 - 15 Participation in Management Decision Making Within Selected Establishments in Lagos, Nigeria. Journal of Social Science, 17 (1): 31-39.

[39] Orodho, J. (2001). Techniques of Writing Research Proposals and Report. Nairobi. KISE

[40] Pollitt, C. (2003). Performance Management in Practice: A Comparative Study of Executive Agencies, Journal of Public Administration Research and Theory 16: 25- 44.

[41] Porter, S. \& Ayman, R. (2010). Work flexibility as a mediator of the relationship between work family conflict and intention to quit. Journal of Management \& Organization, 16, 411- 424.

[42] Preuss, G., \& Lautsch, A. (2002) The Effect of Formal versus Informal Job Security on Employee Involvement Programs. Industrial Relations, 57 (3): 517- 541.

[43] Ranis, G., \& Stewart, F. (2006). Economic growth and human development. Journal of World development Vol 28(2), $197-219$.

[44] RoK. (2013). Report on county governments finance performance for March to June. Nairobi: Office of Controller of Budget.

[45] Rothbard, N. \& Dumas, T. Getting to Know You? Disclosure and Status Distance in Diverse Environments. Academy of Management Annual Meeting, August, 2008

Schultz, T. (1961). Investment in Human Capital. American Economic Review, 51, 1-17.

[46] Shadur, M.A., Kienzle, R., \& Rodwell, J.J. (1999) The Relationship between Organizational Climate and Employee Perceptions of Involvement: The Importance of support. Group and Organization Management, 24 (4); 479-503.

[47] Shirzad, K, Zanganeh, F. (2011). The relationship between senior managers leadership style of school districts of Tehran and spirit of the administrators in girls state school. Journal of Management Research and Training.

[48] Singleton, R. (1993). Approaches to Social Research. New York: Oxford University Press

[49] Stone A. Gregory, Russell F. Robert, Patterson Kathleen (2004) Transformational Versus Servant Leadership - A Difference in Leader Focus, Leadership and Organization development Journal, Vol 25. NO4, PP349-361

[50] Stoner; J.A.F. (2000). Management, New Jersey: Practice Hill Inc.

[51] Ulshafer, S., Potgeisser, M. \& Lima, T. (2005). Concierge services help deliver better work/life balance at Bronson Healthcare Group. Journal of Organizational Excellence, 24 (3), 23- 30.

[52] Zivkovic, Z., Mihajlovic, I., Prvulovic, S. (2009) Developing Motivational Model as a Strategy for HRM in Small Enterprises under Transitional Economy. Serbian Journal of Management, 4(1): 1-27. 